\title{
DNA Fidelity: Expression of a Monocot Promoter in a Dicot Plant
}

\section{Luis María Suárez-Rodríguez ${ }^{1}$, Hugh Mason², Joel Ramírez-Cabrera1, Luis Jorge Saucedo ${ }^{3}$, Miguel Angel Gómez-Lim³, Charles Arntzen², Rodolfo López-Gómez ${ }^{1 *}$}

\author{
${ }^{1}$ Instituto de Investigaciones Químico-Biológicas, Universidad Michoacana de San Nicolás de Hidalgo, Morelia, México \\ ${ }^{2}$ School of Life Sciences, Arizona State University, Tempe, USA \\ ${ }^{3}$ Departamento de Genética Cinvestav IPN Campus Irapuato, Irapuato, México \\ Email: *rodolfo.lopez.gomez@umich.mx
}

How to cite this paper: Suárez-Rodríguez, L.M., Mason, H., Ramírez-Cabrera, J., Saucedo, L.J., Gómez-Lim, M.A., Arntzen, C. and López-Gómez, R. (2022) DNA Fidelity: Expression of a Monocot Promoter in a Dicot Plant. American Journal of Plant Sciences, 13, 50-59.

https://doi.org/10.4236/ajps.2022.131004

Received: November 30, 2021

Accepted: January 15, 2022

Published: January 18, 2022

Copyright (c) 2022 by author(s) and Scientific Research Publishing Inc. This work is licensed under the Creative Commons Attribution International License (CC BY 4.0).

http://creativecommons.org/licenses/by/4.0/

\begin{abstract}
The knowledge generated from the identification of plant promoters has been very important for plant biotechnology development. The use of promoters in transgenic plants allows a reasonable level of regulating protein expression. With the application of reporter genes, such as gus (uidA,) the production of a colored protein, $\beta$-glucuronidase, can be detected and measured both qualitatively and quantitatively, and the activity of the promoter can be assessed. In this work we use a promoter of an abundant banana fruit protein gene Musa acuminata Acidic Chitinase class III a monocot species, to drive expression of gusA in a dicot species, like tomato. We evaluated the monocot promoter capabilities by localizing and quantifying $\beta$-glucuronidase (GUS) expression through fluorometric assays during tomato fruit ripening. Our results suggest that this promoter could be used for specifically strong fruit protein expression in dicot plants.
\end{abstract}

\section{Keywords}

Promoter, Fruit, Ripening, Tomato, Banana

\section{Introduction}

Fruit ripening is a complex metabolic process involving changes in color, flavor, texture, and aroma that are catalyzed by highly regulated specific enzyme activities. The onset of ripening involves the expression of specific genes, and the expression specificity lies in the genes promoter region. Although chitinases are abundant proteins found in a wide variety of plants, the presence of chitin has not been reported in higher plants. Since chitin is the major structural compo- 
nent of fungal cell walls, it has been proposed that chitinases serve as defense proteins with antifungal activity [1]. Chitinases are reported to be induced in higher plants by several different types of stress [2] [3]. Many plant chitinases are expressed although at a low level constitutively [1]. Some evidence exists for the development regulation of chitinase expression in specific tissue and all defined stages during plant development [4] [5] [6]. The abundant $31 \mathrm{KDa}$ banana pulp protein is homologous to class III chitinases [7]. There are several reports about chitinase genes expression during fruit ripening like avocado [8] [9] [10], pineapple [5], grapes [11] and pears [12]. However, in contrast to the ripening associated PR-proteins studied in some fruits, banana acidic chitinase decreases in abundance during ripening [7]. Although it is possible that this banana chitinase serves a protective role during fruit development, an alternate hypothesis is that it serves as a storage protein in this tissue [7] [13]. One of the most abundant proteins in tamarind seeds is an acidic class III chitinase based on its abundance accumulation without any pathogenesis-related stimulus, temporal regulation, amino acid composition, and very low enzyme activity; this $34 \mathrm{KDa}$ protein designated "tamarinin" physiologically serves as the major storage protein [4]. In this work, we isolated a fragment of $2.1 \mathrm{~Kb}$ of the promoter of the banana acidic chitinase class III (MaChIII), and using GUS reaction as reporter gene detected its expression in transgenic tomato fruit (Solanum lycopersicum).

\section{Material and Methods}

\subsection{Genomic Library Construction and Screening}

Banana genomic library for Musa acuminata cv Giant Nain was constructed with DNA isolated from immature green leaves, using the EMBL3 vector (Stratagene) [14]. Approximately, $2 \times 10^{6}$ primary plaques from the genomic library were plated, blotted and hybridized with ${ }^{32} \mathrm{P}$ labeled banana $\mathrm{p} 31$ cDNA [7]. Three successive hybridizations identified positive clones, from which DNA was isolated by restriction mapping. The genomic clone, Musa acuminata acidic chitinase class III was subcloned into plasmid Sport (Invitrogen) and sequenced by Sanger Method (GenBank: AY525367.1).

\section{2. pGPT-31G Vector Construction}

The $2.1 \mathrm{Kbp} 5$ ' region of banana acidic chitinase class III (MaChIII) gene was obtained from genomic DNA clone. The NcoI site at $-1739 \mathrm{bp}$ from the start codon was removed by cutting with $\mathrm{NcoI}$ and filling the ends with Klenow enzyme. Then, a NcoI site was created at the start codon by PCR. The $2.1 \mathrm{Kbp}$ Bam$\mathrm{HI}-\mathrm{NcoI}$ fragment containing the MaChIII promoter was fused to the GUS gene with the CaMV 35S 3' region from pRTL2-GUS [15] and the expression cassette was inserted into pGPTV-Kan [16] to make pGPT-31G vector (Figure 1(A)).

\subsection{Tomato Plant Transformation}

Agrobacterium-mediated transformation of tomato cotyledons (variety Tanksley 


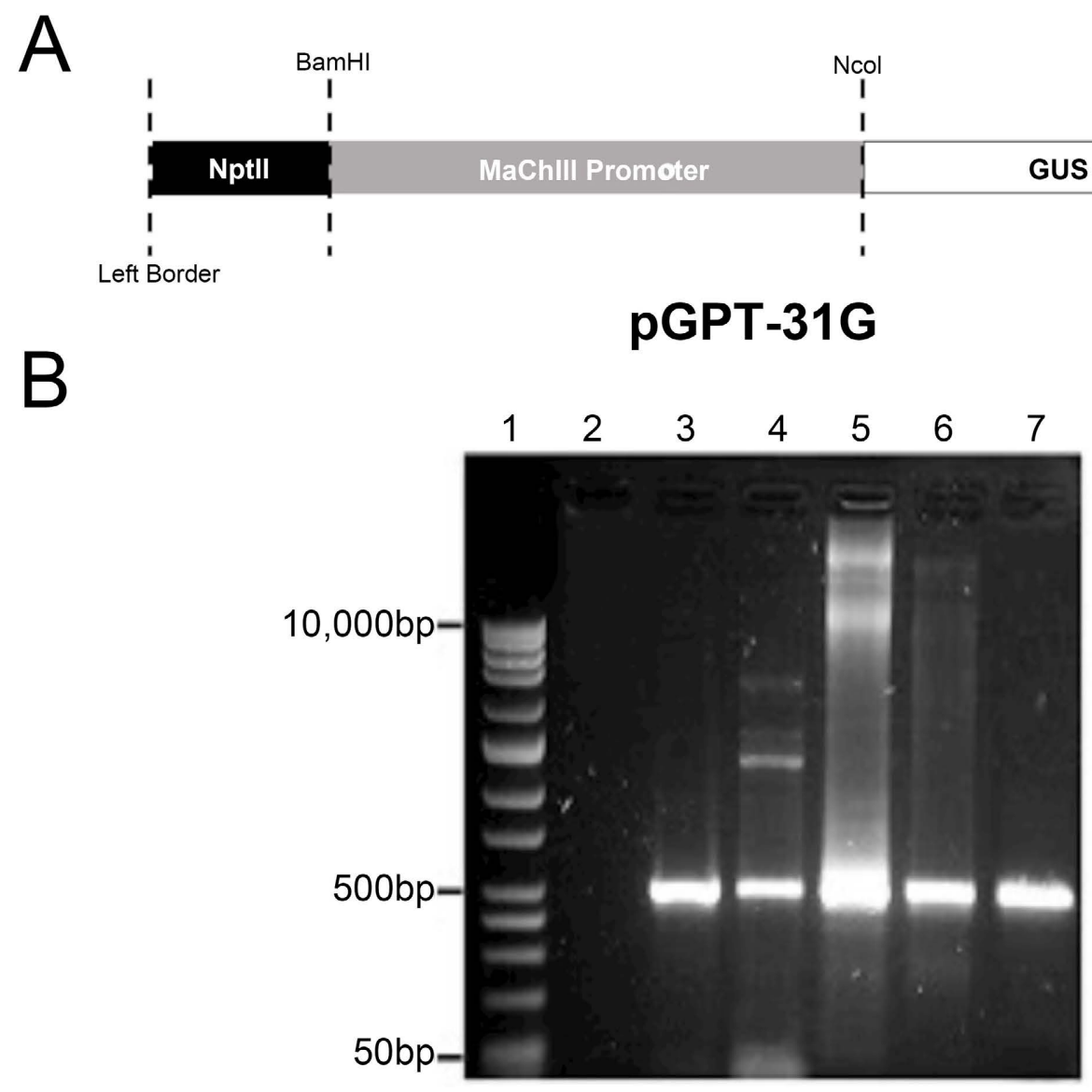

Figure 1. (A) Binary vector map pGPT-35G. GUS gene is under control of banana p31 promoter, CAMV terminator is the 3' end of GUS gene. (B) Banana (Musa acuminata) Acidic Chitinase III (MaChIII) promoter PCR detection. Total DNA was extracted from banana and tomato transgenic lines. The amplified band of $480 \mathrm{bp}$ corresponds to the promoter amplicon. Line 1 molecular weight marker, line 2 negative control wild type tomato DNA, line 3 plasmid DNA with MaChIII construction, line 4 - 6 transgenic tomato lines DNA, line 7 banana DNA.

TA234TM2R) was performed according to Frary [17], except those seeds were sterilized by soaking in 70\% ethanol for $2 \mathrm{~min}$ before rinsing in sterile water and washing in a mixture of $10 \%$ bleach and $1 \%$ Tween- 20 for $10 \mathrm{~min}$. The seeds were rinsed three times in sterile distilled water before plating on half-strength MS medium [18] (half-strength MS: $50 \mathrm{mg} \cdot \mathrm{L}^{-1}$ myo-inositol, $2 \mathrm{mg} \cdot \mathrm{L}^{-1}$ thiamine $\mathrm{HCl}, 0.5 \mathrm{mg} \cdot \mathrm{L}^{-1}$ pyridoxine $\mathrm{HCl}, 0.5 \mathrm{mg} \cdot \mathrm{L}^{-1}$ nicotinic acid, $10 \mathrm{~g} \cdot \mathrm{L}^{-1}$ sucrose and 8 $\mathrm{g} \cdot \mathrm{L}^{-1}$ Difco bacto agar, $\mathrm{pH}$ 5.8). Plantlets were regenerated on medium containing kanamycin at $300 \mathrm{mg} / \mathrm{L}$.

\subsection{PCR MaChIII Promoter Detection}

PCR MaChIII promoter fragment was amplified from transgenic tomato lines using total DNA as template and two internal primers for a $480 \mathrm{bp}$ fragment of the promoter sequence (promoter region 1691 to $2152 \mathrm{pb}$ ): MaPromP31FW CCA AGA GGA TTT AAA TTT GGG C and MaPromP31RW CGG GGA CTT GTC GAA GTT TTC G under the following conditions: 5 min denaturation at $95^{\circ} \mathrm{C}$, followed by 25 cycles of amplification $\left(95^{\circ} \mathrm{C}\right.$ for $30 \mathrm{~s}, 57^{\circ} \mathrm{C} 30 \mathrm{~s}, 72^{\circ} \mathrm{C} 30 \mathrm{~s}$ ) 
in an Applied Biosystems 2720 Thermal Cycler.

\subsection{Analysis of $\beta$-Glucuronidase (GUS) Expression by Fluorometry}

We made fluorometric GUS assay following the method described by Jefferson [19]. Samples of leaves and fruits tissues were assayed. Transgenic tomatoes fruits were pick up at three ripening stages; green, brake and red (ripen). Fruits were divided in pericarp and placenta tissues. The volume equivalent to $20 \mu \mathrm{g}$ of protein was incubated with $1 \mathrm{mM} \mathrm{MUG}$ buffer at $37^{\circ} \mathrm{C}$ for $90 \mathrm{~min}$. The enzymatic reaction was measured by spectrofluorometer Bio-Rad VersaFluor fluorometer (Bio-Rad Laboratories, Hercules, CA). Fluorescence was measured at an excitation wavelength of $365 \mathrm{~nm}$ and an emission wavelength of $450 \mathrm{~nm}$. Proteins were extracted from different tissues and total protein concentration was determined according to Bradford assay and bovine serum albumin as standard. All the samples had three repetitions. To determine the $\mathrm{pmol} / \mathrm{min} / \mathrm{mg}$ value in each sample, a MU standard curve was constructed from the standard readings and absolute amount of MU (nM). Samples O.D. readings were applied to the equation, and a linear estimation was done to get protein activity/minute. The slope value (nM/min) was obtained for each sample, and conversions were applied to convert $\mathrm{nM}$ to nmolar, and then to $\mathrm{nmol} / \mathrm{min}$. Using the values obtained from the Bradford standard curve and several dilution factors, a value was obtained for each sample in units of $\mathrm{pmol} / \mathrm{min} / \mathrm{mg}$.

\subsection{Histochemical Assay}

Fruit sections were cut by hands and fixed in $0.3 \%$ formaldehyde in $10 \mathrm{mM}$ MES, pH 5.6, $30 \mathrm{mM}$ mannitol for $45 \mathrm{~min}$ at room temperature followed by several washes in $50 \mathrm{mM} \mathrm{NaH}_{2} \mathrm{PO}_{4}, \mathrm{pH}$ 7.0. The samples were put in $1 \mathrm{mM} \mathrm{X-Gluc}$ (5-bromo-4-cloro-3-indolyl- $\beta$-glucuronic acid) solution and incubated at $37^{\circ} \mathrm{C}$ overnight for blue color development [19].

\section{Results and Discussion}

\subsection{Analysis of p31 Promoter Expression in Tomato Plants}

The banana acidic chitinase promoter vector pGPT-31G was introduced into $A$. tumefaciens LBA4404 by electroporation. Transformants were selected on LB medium containing kanamycin and confirmed by PCR. Using pGPT-31G vector Tomatoes cotyledons were transformed using Agrobacterium system. Four transgenic plant lines were obtained; we chose the line GPT31G-2 for the next experiments. Transgenic line was grown under greenhouse conditions and grown over a period of six months. Tomato total DNA was obtained and used for PCR assays to verify the MaChIII promoter incorporation in the tomato genome (Figure 1(B)).

\subsection{Fluorometry Analysis of $\beta$-Glucuronidase (GUS) Expression}

Samples from pericarp and placenta of transgenic tomato fruits of GPT31G-2 
line at three stages of tomato fruit ripening; green, brake and ripen, were collected. We made fluorometric assay in these three tomato ripening tissues and leaves samples. Data was quantified, and then arrayed in column graphs plotting the $\mathrm{pmol} / \mathrm{min} / \mathrm{mg}$ values obtained for each sample. We can observe that the higher expression is specified in the pericarp and placental regions at tomato brake stage. Low values were obtained in pericarp and placenta tissues of green and ripen stages of tomato fruit ripening. Fluorometric leaves values are lower than obtained from fruit tissues (Figure 2(A)).

\subsection{Histochemical Fruit GUS Staining Assay}

Figures 2(D)-(I) shows histochemical tomato GUS assays in the three tomato fruit ripening stages (green, break and ripe). In tomato green fruits the expression is confined to the vascular and funiculus tissues (Figure 2(D) \& Figure 2(E)). In the tomato brake stage, the blue staining is hard in all pericarp, locular gel, vascular and placental tissues (Figure 2(F) \& Figure 2(G)). This ripening stage is just before climacteric ethylene burst. During the ripen stage (red) after the climacteric period the expression was reduced to vascular and funiculus fruit tissues (Figure 2(H) \& Figure 2(I)). This pattern of expression is like to the

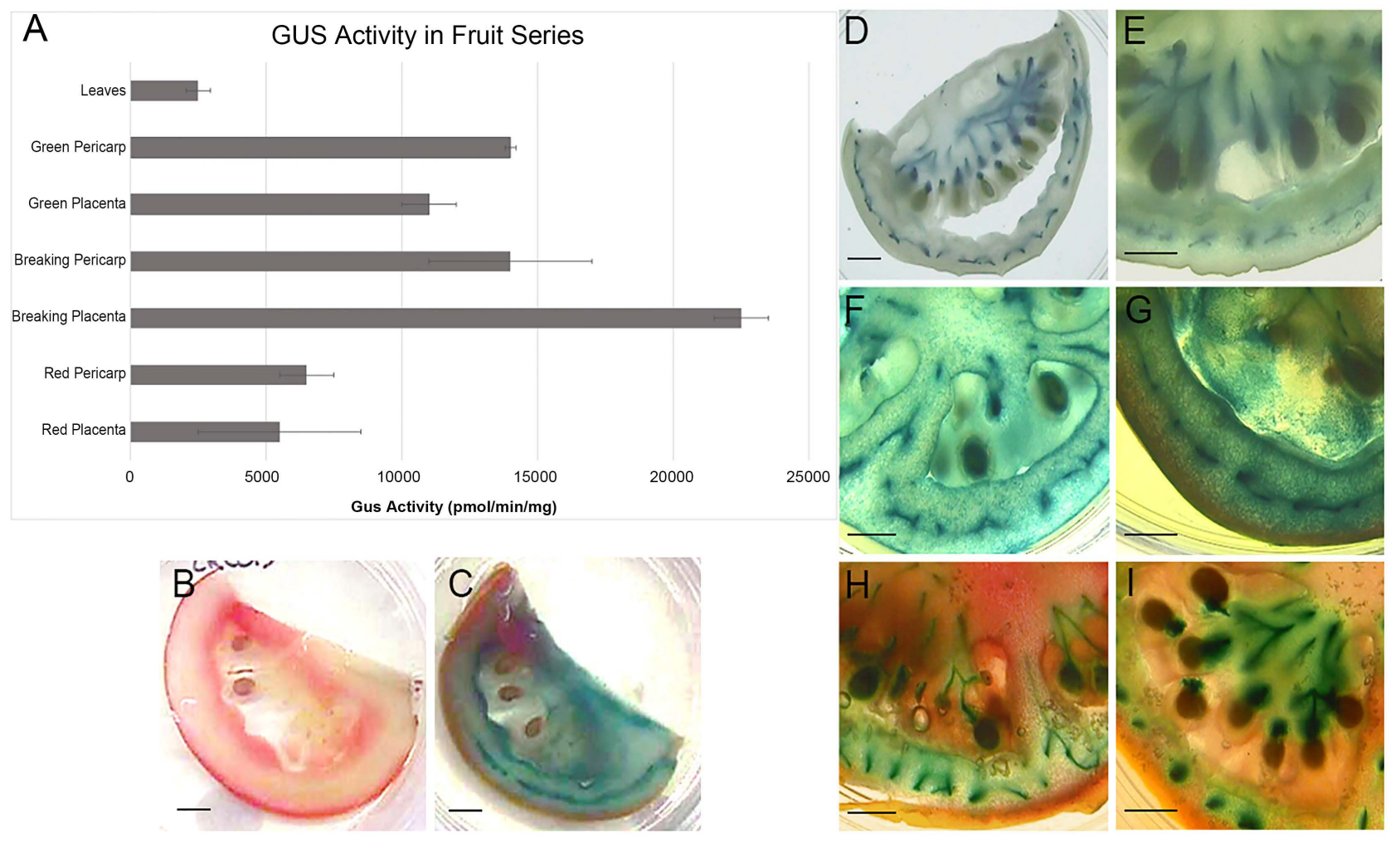

Figure 2. (A) Analysis of $\beta$-glucuronidase (GUS) expression under the control of p31 promoter through fluorimetry. Protein was extracted from transgenic tomatoes fruits at three ripening stages; green, brake and red (ripen). Fruits were divided in pericarp and placenta tissues. Leaves samples of transgenic plants were processed too. (B - C) Negative and Positive controls of transgenic tomato GUS staining. (D - I) GUS staining of tomatoes fruits carrying MaChIII promoter. Tomatoes sections of three fruit ripening stages. (D - E) Green stage; (F - G) Breaking stage; (H - I) Red stage; GUS expression under the control of banana acidic chitinase clasIII promoter. Rules $0.5 \mathrm{~cm}$. 
acidic chitinase class III banana protein expression during fruit ripening [7]. The expression of the banana acidic chitinase class III promoter in a dicot model plant like tomato is interesting and suggests that this sequence gives organ specificity to the coding region and that is associated to fruit development too. The turn off the expression of the gene in presence of ethylene is similar, when climacteric ethylene production occurs during fruit ripening, the promoter turns off the expression of the gene in pericarp and placenta tissue. An interesting observation is the funiculus intense expression during three ripening stages, this result suggests that this acidic chitinase could be involved in seed development. Banana express abundantly this gene in the green pericarp like tomato, both fruits before of climacteric fruit stage.

\subsection{In Silico p31 Promoter Analysis}

The sequence of the 5' flanking promoter DNA of the MaChIII was determined. The likely start codon is located at position 2153 . The putative cis-element of this promoter was analyzed using PLANT Care program and Table 1 . The TATA Box was found at position 1043. Potential regulatory cis elements associated with phytohormones, and stress related response were located within the MaChIII promoter, including $1 \mathrm{~W}$-box, 5 light response, 4 stress, 3 Abscisic Acid, 1 Methyl JA and 4 for transcription factors related elements. The presence of these elements demonstrates that MaChIII may be involved in banana response to biotic and abiotic stresses and development more than pathogenic response.

Table 1. Prediction cis-acting elements of MaChIII promoter using PLANT CARE database analysis.

\begin{tabular}{cccc}
\hline Motif name & Sequence & Function & Motif No \\
\hline AAGAA-motif & GAAAGAA & Unknown & 2 \\
ABRE & ACGTG & Abscisic acid responsive element & 3 \\
ABRE3a & TACGTG & Abscisic acid responsive element & 2 \\
ABRE4 & CACGTA & Abscisic acid responsive element & 1 \\
ARE & AAACCA & cis-acting regulatory element essential & 3 \\
& for the anaerobic induction & \\
CAAT-box & CAAT & Common cis-acting element in & 24 \\
CGTCA-motif & CGTCA & promoter and enhancer regions & 1 \\
GBOX & TACGTG & Methyl JA-response & 2 \\
LAMP Element & CCTTATCCA & Part of light responsive element & 1 \\
MBS & CAACTG & MYB binding site involved in & 1 \\
MYB & TAACCA & drought-inducibility & 1 \\
MYB like & TAACCA & Stress response & 2 \\
MYC & CAATTG & Stress response & Stress response \\
\hline
\end{tabular}




\begin{tabular}{|c|c|c|c|}
\hline Continued & & & \\
\hline Myb & CAACTG & MYB binding related Cis-elements & 1 \\
\hline Myc & TCTCTTA & Unknown & 1 \\
\hline STRE & AGGGG & Stress response element & 3 \\
\hline Sp1 & GGGCGG & Light responsive element & 1 \\
\hline TATA Box & & Core promoter element & \\
\hline TCA & TCATCTTCAT & Salicilic acid responsiveness & 1 \\
\hline TCT-motif & TCTTAC & Part of light responsive element & 2 \\
\hline Unnamed__4 & CTCC & Unknown & 9 \\
\hline W box & TTGACC & Stress response & 2 \\
\hline
\end{tabular}

\section{Discussion}

Although chitinases are a family of antifungal proteins, the precise functions of individual members in this family and their expressional mechanism are still largely unknown. From deduced amino acid sequence of MaChIII only three of the five amino acids necessary for chitinase activity are conserved. We reported previously that the abundance of MaChIII decreased as ripening proceeded. The MaChIII antibody recognized a single $31 \mathrm{KDa}$ polypeptide in banana pulp that was not present in peel, corm meristem or root tissues. These results indicated that this chitinase is fruit-specific and its physiological role is not for plant protection, but as a storage protein in banana pulp [7]. It is possible that this promoter response is associated in a tissue-specific way in tomato fruit [20], as found with the regulation of ethylene biosynthesis in the different tomato fruit tissues [21]. Another interesting observation is the very specific GUS staining of the fruit vascular tissue in the three stages of ripening. This suggests that this promoter could be carpel-specific. More studies are necessary since banana fruit is a parthenocarpy fruit.

In silico analysis shows that this promoter presents cis-acting elements principally related to stress, development and phyto-regulators response does not have pathogen cis-acting elements, like W Boxes present in chitinase promoters reported in other plants with antifungal activity [22]. The GUS staining expression of MaChIII in tomato fruit showed similar behavior like banana fruit, its expression goes down during fruit ripening and the higher expression was in green and breaking pericarp and placenta of preclimacteric tomato fruit.

\section{Conclusion}

Taken together our results suggest that expression of this promoter is developmentally regulated rather than pathogen-induced. It gives organ specificity expression during fruit ripening, and at least, this fruit promoter should have sequences that are conserved between the two genome systems (monocots and dicots plants) during fruit ripening and development. It is possible that in the evolution of plants promoter sequences could be conserved too. This promoter 
could have biotechnological applications, could be useful for the expression of proteins during fruit ripening of monocots and dicots plants, like oral vaccines.

\section{Acknowledgements}

We thank Sara Welch and Lorena Carreto-Motoya for their technical support.

\section{Conflicts of Interest}

The authors declare no conflicts of interest regarding the publication of this paper.

\section{References}

[1] Collinge, D.V., Kragh, K.M., Mikkelsen, J.D., Nielsen, K.K., Ramussen, U. and Vad, K. (1993) Plant Chitinases. The Plant Journal, 3, 31-40. https://doi.org/10.1046/j.1365-313X.1993.t01-1-00999.x

[2] Takenaka, Y., Nakano, S., Tamoi, M., Sakuda, S. and Fukamizo, T. (2009) Chitinase Gene Expression in Response to Environmental Stresses in Arabidopsis thaliana: Chitinase Inhibitor Allosamidin Enhances Stress Tolerance. Bioscience, Biotechnology, and Biochemistry, 73, 1066-1071. https://doi.org/10.1271/bbb.80837

[3] Grover, A. (2012) Plant Chitinases: Genetic Diversity and Physiological Roles. Critical Reviews in Plant Sciences, 31, 57-73. https://doi.org/10.1080/07352689.2011.616043

[4] Rao, D.H. and Gowda, L.R. (2008) Abundant Class III Acidic Chitinase Homologue in Tamarind (Tamarindus indica) Seed Serves as the Major Storage Protein. Journal of Agricultural and Food Chemistry, 56, 2175-2182. https://doi.org/10.1021/jf073183i

[5] Taira, T., Toma, N., Ichi, M., Takeuchi, M. and Ishihara, M. (2005) Tissue Distribution, Synthesis Stage, and Ethylene Induction of Pineapple (Ananas comusus) Chitinases. Bioscience, Biotechnology, and Biochemistry, 69, 852-854. https://doi.org/10.1271/bbb.69.852

[6] Regalado, A.P., Pinheiro, C., Vidal, S., Chaves, I., Ricardo, C.P.P. and RodriguesPousad, C. (2000). The Lupinus albus Class-III Chitinase Gene, IF3, Is Constitutively Expressed in Vegetative Organs and Developing Seeds. Planta, 210, 543-550. https://doi.org/10.1007/s004250050043

[7] Clendennen, S.K., López-Gómez, R., Gómez-Lim, M.A., Arntzen, C.J. and May, G.D. (1998) The Abundant 31-Kilodalton Banana Pulp Protein Is Homologous to Class III Acidic Chitinases. Phytochemistry, 47, 613-619. https://doi.org/10.1016/S0031-9422(97)00616-X

[8] López-Gómez, R.., Suáres-Rodríguez, L.M., Ibarra-Laclette, E., Guzmán-Rodríguez, J.J., López-Meza, J.E., Ochoa-Zarzosa, A., Salgado-Garciglia, R., Rodríguez-Zapata, L.C., Jimenéz-Moraila, B. and Herrera-Estrella, L. (2016) Transcriptome (ESTs) of Native Mexican Avocado Fruit Is Dominated by Stress and Innate Immunity Genes. Acta Horticulturae 1144, 43-48. https://doi.org/10.17660/ActaHortic.2016.1144.6

[9] Dopico, B., Lowe, A.L., Wilson, I.D., Merodio, C. and Grierson, D. (1993) Cloning and Characterization of Avocado Fruit mRNAs and Their Expression during Ripening and Low-Temperature Storage. Plant Molecular Biology, 21, Article No. 437. https://doi.org/10.1007/BF00028802

[10] Sowka, S., Hsieh, L.S., Krebitz, M., Akasawa, A., Martin, B.M., Starretti, D., Peter- 
bauer, C., Scheiner, O. and Breiteneder, H. (1998) Identification and Cloning of Prs a 1, a 32-kDa Endochitinase and Major Allergen of Avocado, and Its Expression in the Yeast Pichia pastoris. Journal of Biological Chemistry, 273, 28091-28097. https://doi.org/10.1074/jbc.273.43.28091

[11] Ano, A., Yanagi, T.T., Uchibori, T., Okuda, T. and Yokotsuka, K. (2003) Characterization of a Class III Chitinase from Vitis vinifera cv Koshu. Journal of Bioscience and Bioengineering, 95, 645-647. https://doi.org/10.1016/S1389-1723(03)80179-2

[12] Akihiro, I., Kenji, T., Fumio, T. and Toshico, T. (2000) Isolation of cDNA Clones Corresponding to Genes Expressed during Fruit Ripening in Japanese Pear (Pyrus pirifolia Nakai): Involvement of the Signal Transduction Pathway in Their Expression. Journal of Experimental Botany, 51, 1163-1166.

https://doi.org/10.1093/jexbot/51.347.1163

[13] Peumans, W.J., Proost, P., Swennen, R.L. and Van Damme, E.J.M. (2002) The Abundant Class III Chitinase Homolog in Young Developing Banana Fruits Behaves as a Transient Vegetative Storage Protein and Most Probably Serves as an Important Supply of Amino Acids for the Synthesis of Ripening-Associated Proteins. Plant Physiology, 130, 1063-1072. https://doi.org/10.1104/pp.006551

[14] López-Gómez, R., Campbell, A., Dong, J.G., Yang, S.F. and Gómez-Lim, M.A. (1997) Ethylene Biosynthesis in Banan Fruit: Isolation of a Genomic Clone to ACC Oxidase and Expression Studies. Plant Science, 123, 123-131. https://doi.org/10.1016/S0168-9452(97)04578-0

[15] Carrington, J.C., Freed, D.D. and Leinicke, A.J. (1991) Bipartite Signal Sequence Mediates Nuclear Translocation of the Plant Potyviral Nla Protein. Plant Cell, 3, 953-962. https://doi.org/10.1105/tpc.3.9.953

[16] Becker, D., Kemper, E., Schell, J. and Masterson, R. (1992) New Plant Binary Vectors with Selectable Markers Located Proximal to the Left T-DNA Border. Plant Molecular Biology, 20, 1195-1197. https://doi.org/10.1007/BF00028908

[17] Frary, A. and Earle, E.D. (1996) An Examination of Factors Affecting the Efficiency of Agrobacterium-Mediated Transformation of Tomato. Plant Cell Reports, 16, 235-240.

[18] Murashige, T. and Skoog, F. (1962) A Revised Medium for Rapid Growth and Bioassays with Tobacco Tissue Cultures. Physiologia Plantarum, 15, 473-497. https://doi.org/10.1111/j.1399-3054.1962.tb08052.x

[19] Jefferson, R.A., Kavanagh, T.A. and Bevan, M.W. (1987) GUS Fusions: Beta-Glucuronidase as a Sensitive and Versatile Gene Fusion Marker in Higher Plants. The EMBO Journal, 6, 3901-3907. https://doi.org/10.1002/j.1460-2075.1987.tb02730.x

[20] Matas, A.J., Yeats, T.H., Buda, G.J., Zheng, Y., Chatterjee, S., Tohge, T., Ponnala, L., Adato, A., Aharoni, A., Stark, R., Fernie, A.R., Fei, Z., Giovannoni, J.J. and Rosea, J.K.C. (2011) Tissue- and Cell-Type Specific Transcriptome Profiling of Expanding Tomato Fruit Provides Insights into Metabolic and Regulatory Specialization and Cuticle Formation. The Plant Cell, 23, 3893-3910.

https://doi.org/10.1105/tpc.111.091173

[21] Van de Poel, B., Vandenzavel, N., Smet, C., Nicolay, T., Bulens, I., Mellidou, I., Vandoninck, S., Hertog, M.L., Derua, R., Spaepen, S., Vanderleyden, J., Waelkens, E., De Proft, M.P., Nicolai, B.M. and Geeraerd, A.H. (2014) Tissue Specific Analysis revEals a Differential Organization and Regulation of Both Ethylene Biosynthesis and E8 during Climacteric Ripening of Tomato. BMC Plant Biology, 14, Article No. 11. https://doi.org/10.1186/1471-2229-14-11

[22] Liu, Z., Shi, L., Yang, S., Lin, Y., Weng, Y., Li, X., Hussain, A., Norman, A. and He, 
S. (2017) Functional and Promoter Analysis of ChiIV3, a Chitinase of Pepper Plant, in Response to Phytophthora capsici Infection. International Journal of Molecular Science, 18, Article No. 1661. https://doi.org/10.3390/ijms18081661 